\title{
Evaluation of mandibular asymmetry in class II subdivision malocclusion
}

\author{
Mehmet Akın ${ }^{1}$, Zehra Ileri ${ }^{1}$, Ömer Polat ${ }^{1}$, Faruk Ayhan Başçiftçi ${ }^{1}$
}

Selcuk Dental Journal, 2015; 2: 43-50

Bașvuru Tarihi: 02 Nisan 2015 Yayına Kabul Tarihi: 24 Nisan 2015

\section{Sınıf II subdivizyon maloklüzyonda mandibular asimetrinin değerlendirmesi}

Amaç: Bu çalışmanın amacı Sınıf II subdivizyon maloklüzyonlardaki mandibular iskeletsel asimetrilerin prevalansını, Sınıf I ve Sınıf II maloklüzyonlarla karşılaşırmalı olarak belirlemektir.

Gereç ve Yöntemler: Çalışmaya her biri 40'ar bireyden oluşan 3 grup dahil edilmiştir: bir Sınıf I oklüzyon grubu (14 erkek ve 26 kadın; yaş ortalaması 14.68 \pm 1.86 ), bir Sınıf II oküzyon grubu (12 erkek, 28 kadın ; yaş ortalaması 14.02 1.74 ), ve sınif II subdivizyon oklüzyon grubu (19 erkek and 21 kadın; yaş ortalaması 14.32 \pm 2.42 ). Her bir hasta için panoramik radyogramlarda(OPG) sekiz doğrusal ve bir açısal ölçüm yapılmıştır. Sağ ve sol ya da Sınıf I ve Sınıf II tarafların ölçümlerini kıyaslamak için Wilcoxon testi kullanılmıştır. Grup içi değerlendirmelerde $P \quad<0,05$ seviyesindeki asimetrilerin kıyaslanması için Kruskal-Wallis ve post-hoc Mann- Whitney U testleri kullanılmıştır.

Bulgular: Sınıf I ve Sınıf II veya subdivizyon grubundaki bireylerin Sınıf I tarafları ve Sınıf II tarafları veya sağ sol tarafları arasında, yalnızca gonial açıda anlamlı farklılık gözlenmiştir $(\mathrm{P}<0.05)$. Sınf II subdivizyon grubundaki kondil boyları ve korpus uzunluklarındaki asimetri indeksleri diğer gruplara kıyasla daha büyüktür $(P<0.05)$ ve diğer asimetri indeksleri açısından gruplar arasında anlamlı bir farkllık gözlenmemiştir $(P<0.05)$.

Sonuçlar: Sınıf II subdivizyon grubundaki bireyler, Sınıf I ve Sınıf Il gruplarındakilere kıyasla daha asimetrik mandibulaya sahiptir.

\section{KEY WORDS}

Asimetri, asimetri indeksi, alt çene asimetri, sınıf II subdivizyon

\footnotetext{
${ }^{1}$ Selcuk University Faculty of Dentistry Department of Orthodontics, Konya, Turkey
}

Class II subdivision, which has been classified by Angle (1899), have Class I characteristics on one-side and Class II characteristics on the other side. Primarily, it has been shown to be due to distal eruption of the mandibular first molars in relation to normally positioned maxillary first molars (Alavi et al 1988, Rose et al 1994, Janson et al 2001). However, mesial positioning of the maxillary first molar in relation to the mandibular first molar can also cause this malocclusion (Alavi et al 1988).

Generally, the maxillary dental midline shows no or minimal deviation relative to the clinical facial midline; however, the mandibular dental midline shows severe deviation toward the Class II side relative to the clinical facial midline. The conventional treatment of Class II subdivision malocclusion, which is characterized by dentoalveolar asymmetry, presents difficulties for clinicians because of the requirement of the extraction of 2 maxillary premolars and 1 mandibular premolar on the Class I side (Cheney 1952, Burstone 1998). The alternative treatments of Class II subdivision malocclusion are removable or fixed functional appliancies and surgical (Bock et al 2013).

Rose et al (1994) reported that in Class II subdivision malocclusion, only mandibular dentition was found to be asymmetric; there was no unusual skeletal positioning or skeletal asymmetry. In another study Azevededo et al (2006) supported these results. On the other hand, Janson et al (2007) showed that skeletal positioning was not innocent in Class II subdivision malocclusion, and there was a 
tendency for mandibular asymmetry compared with the control group. Kurt et al (2008) investigated condylar asymmetry in Class II subdivision and found that the Class II subdivision group exhibited greater condylar, ramal, and condylar-ramal height values than the control group.

A review of the literature revealed that, there is no consensus about whether skeletal positioning is associated with dental asymmetry in Class II subdivision malocclusion. Therefore, we aimed to investigate mandibular asymmetry in a group of subjects with Class II subdivision malocclusion and compare these data with that from subjects with normal occlusion and Class II malocclusion.

\section{MATERIALS AND METHODS}

This study was approved by the Regional Ethical Committee on Research of the Selcuk University in Konya. The power analysis was established by G*Power version 3.0 .10 software (Franz Faul Universitat, Kiel, Germany) software. Based on the 1:1 ratio between groups, a sample size of 40 subjects per group imparts more than $80 \%$ power (actual power $=0.8358$ ) to detect significant differences with a 0.30 effect size (refers to the magnitude of the effect under the alternate hypothesis) and at the $\alpha=.05$ significance level.

The samples consisted of 3 groups of 40 subjects in each (Group I-normal occlusion; between $0-4^{\circ}$ ANB angle, Group II-Class II Division I malocclusion; between 4-8 $8^{\circ}$ ANB angle and Class II molar relation, and 3- Class II subdivision malocclusion; between $0-4^{\circ}$ ANB angle and one side Class I molar and canine other side Class II molar and canine relation). Intraoral photographs, lateral cephalometric radiograms and stone casts were used to classify the subjects according to their occlusion or malocclusion. These classifications were also verified by two orthodontists separately by remeasuring. The present study was performed using orthopantomograms (OPG) derived from each subject. All OPGs were taken in a standard manner, with the same digital X-ray machine (Planmeca, Helsinki, Finland), and by the same technician. The groups were selected from archives of the Selcuk University, Faculty of Dentistry and Department of Orthodontics. The demographic distribution in different groups for all subjects is shown in Table 1.
Table 1

\section{Mean and standard deviations (SD) of chronological ages for each group}

\begin{tabular}{lllcc} 
& & \multicolumn{3}{c}{ Age, Years } \\
\cline { 2 - 5 } Groups & Gender & N & Mean & SD \\
\hline \multirow{3}{*}{ Class I } & Male & 14 & 15,26 & 1,72 \\
\cline { 2 - 5 } & Female & 26 & 14,34 & 2,12 \\
\cline { 2 - 5 } Class II & Total & 40 & 14,68 & 1,86 \\
\hline \multirow{3}{*}{ Class II Sub } & Male & 12 & 14,56 & 1,45 \\
\cline { 2 - 5 } & Female & 28 & 13,67 & 2,05 \\
\cline { 2 - 5 } & Total & 40 & 14,02 & 1,74 \\
\cline { 2 - 5 } & Male & 19 & 14,42 & 2,34 \\
\hline & Total & 40 & 14,32 & 2,42 \\
\hline
\end{tabular}

Only those OPGs containing no artifacts, and with sufficient contrast to perform all the intended measurements were chosen. The chosen OPGs were analyzed using the QuickCeph Studio (Quick Ceph Systems, San Diego, Calif) software package. Measurements were performed as described by Rickets (1961), Habets et al (1987), Joondeph (2001).

In Group I, subjects who satisfied the following inclusion criteria were selected: (1) Skeletal Class I relationship (0-4 ANB angle) with normal vertical growth and development (28-36 SN-GoGn angle) (2) Class I molar and canine relationship with minor or no crowding, (3) All teeth present except third molars (all of the third molars were impacted), (3) No apparent facial asymmetry determined from extra oral photographs (Azedevo et al 2006), (4) No significant problems in medical history, and (5) No history of trauma, any previous prosthodontics or orthodontic treatment.

In Group II, subjects who fulfilled the following inclusion criteria were selected: (1) Skeletal Class II relationship (4$8^{\circ}$ ANB angle) with normal vertical growth and development (28-36 $\mathrm{SN}-\mathrm{GoGn}$ angle), (2) Other criteria like as Group I.

In Group III, subjects who fulfilled the following inclusion criteria were selected: (1) Class I molar and canine relationship on one side and at least half premolar mesiodistal length of Class II molar and canine relationship on other side, (2) Other criteria like as Group I. 


\section{Mandibular Dimensions}

The following measurements were undertaken on both sides of each OPG by the same author (OP) (Figure 1).

- Condylar Height $(\mathrm{CH})$ : The vertical distance between the lateral points of the condylar image and the most superior point of the condylar image.

- Ramal Height $(\mathrm{RH})$ : The vertical distance between the lateral points of the condylar image and the lateral points of the ramus image.

- Condylar plus Ramal Height $(\mathrm{CH}+\mathrm{RH})$.

- Corpus Length (I-ML): The vertical distance between the lateral points of the ramus image and the mandibular midline.

- Corpus Base Length: (CD): The vertical distance between two inferior points of the corpus image.

- Ramus Height (R1-R2): The vertical distance between the deepest point of the mandibular ramus notch and the lower border of the mandible.

- Ramus Width (R3-R4): The vertical distance between the deepest point of the anterior border of the mandibular ramus and the posterior border of the ramus.

- Corpus Height (M1-M2): The vertical distance between the lowest mesial point of the permanent first lower molar at the cemento-enamel junction and the lower border of the corpus. Parallel to the mandibular midline.

- Gonial Angle (GA): The angle between the line of $\mathrm{RH}$ and the line of $C D$. (Ramirez-Yañez et al 2011).

To determine the mandibular asymmetry for each of the linear and angular measurements, the following formula, developed by Habets et al (1988) was used:

Asymmetry Index $(\mathrm{Al})=[($ Right-Left $) /($ Right + Left $)] \times 10 \%$

\section{Statistical Analysis}

To determine the level of error associated with the radiographic measurements, 20 radiographs were randomly selected and their tracings were repeated 6 weeks after the first measurements by the same author. A Bland-Altman plot was

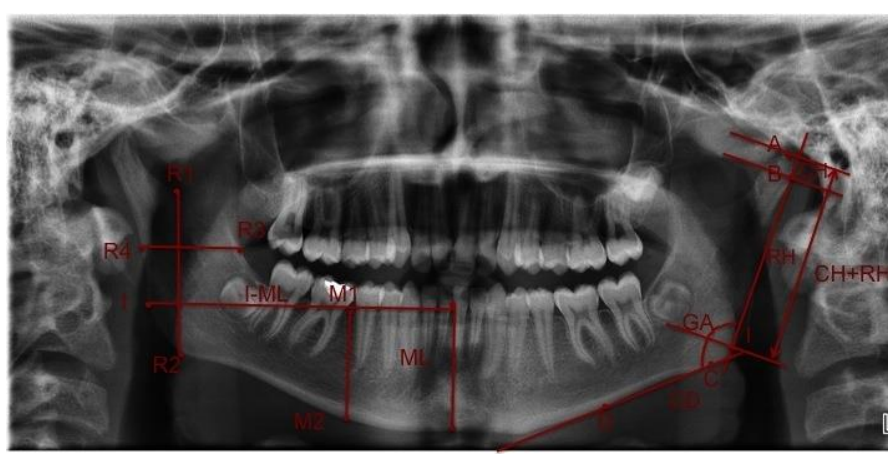

Figure 1.

Panoramic radiograph showing the landmark points and linear and angular measurements used in this study. CH; Condylar Height, RH; Ramal Height, $\mathbf{C H}+\mathbf{R H}$; Condylar plus Ramal Height, I-ML; Corpus Length, CD; Corpus Base Length, R1-R2; Ramus Height, R3-R4; Ramus Width, M1M2; Corpus Height, GA; Gonial Angle.

generated to assess the repeatability, and no significant differences were found between the first and second measurements (Table 2). The standart deviation value of $\mathrm{CH}$ measrements was high. The reason of this result was shortest measurement of $\mathrm{CH}$ in measurements regimen.

Table 2.

\section{Bland-Altman plot to assess the repeatability}

\begin{tabular}{|lcrrrr} 
& Correlation & Bias & $95 \%$ Cl & SE & SD differences \\
\hline CH & 0.21 & 0,65 & 0.612 to 0.752 & 0,03 & 2,631 \\
\hline RH & 0.14 & 0.86 & 0.613 to 0.954 & 0,09 & 0,345 \\
\hline CH+RH & 0.19 & 0.19 & 0.146 to 0.295 & 0,31 & 0,532 \\
\hline I-ML & -0.04 & 0.326 & 0.268 to 0.395 & 0,05 & 0,211 \\
\hline CD & -0.23 & 0.173 & 0.141 to 0.264 & 0,04 & 0,107 \\
\hline R1-R2 & 0.04 & 1,121 & 0.965 to 1.231 & 0,12 & 0,341 \\
\hline R3-R4 & -0.17 & 0,832 & 0.698 to 1.076 & 0,09 & 0,296 \\
\hline M1-M2 & 0.16 & 0,314 & 0.114 to 0.508 & 0,11 & 0,205 \\
\hline GA & 0.31 & 1,041 & 0.812 to 1.195 & 0,21 & 0,412 \\
\hline
\end{tabular}

SE: Standard Error; SD: Standard Deviation $\mathrm{a}=\mathrm{Cl}$ indicates confidence interval

All statistical analyses were performed by using the Statistical Package for the Social Sciences (version 17.0 for Windows; SPSS, Chicago, III). The normality test of Kolmogorow-Smirnov variance homogeneity was applied to the data. The data were not distributed normally; therefore the statistical evaluations of these data were performed using nonparametric tests. 
Intragroup comparisons were evaluated by using the Wilcoxon test, and intergroup changes were analyzed with Kruskal-Wallis test. Post-hoc comparisons were performed using the MannWhitney U-test test. When the $P$ value was less than 0.05 , the statistical test was determined to be significant.

\section{RESULTS}

Descriptive statistics (means, standard deviations) and statistical comparisons of the linear and angular measurements for the intra group comparisons are shown in the Table 3 . The results of Wilcoxon tests showed that there were significant differences in gonial angle measurements in all groups $(P<0.05)$, and also in condylar height, corpus length, and corpus base length measurements in Group III ( $\mathrm{P}<0.05)$.

Table 3.

\section{Statistical right and left or Class I and Class II sides comparisons of groups}

\begin{tabular}{|c|c|c|c|c|c|c|c|c|c|}
\hline \multirow[b]{3}{*}{ Measurements } & \multicolumn{2}{|c|}{ Class I } & \multicolumn{3}{|c|}{ Class II } & \multicolumn{4}{|c|}{ Class II Subdivision } \\
\hline & Right & Left & & Right & Left & & Class I & Class II & \\
\hline & Mean $\pm S D$ & Mean $\pm S D$ & Sign & Mean $\pm S D$ & Mean $\pm S D$ & Sign & Mean $\pm S D$ & Mean $\pm S D$ & Sign \\
\hline $\mathrm{CH}$ & $8.32 \pm 2.08$ & $8.12 \pm 1.98$ & NS & $7.78 \pm 2.21$ & $7.95 \pm 2.03$ & NS & $8.03 \pm 1.97$ & $7.19 \pm 2.24$ & $P=0.042^{*}$ \\
\hline $\mathrm{RH}$ & $48.08 \pm 4.36$ & $47.86 \pm 5.12$ & NS & $47.98 \pm 4.48$ & $46.84 \pm 5.36$ & NS & $48.44 \pm 5.08$ & $46.92 \pm 5.58$ & NS \\
\hline $\mathrm{CH}+\mathrm{RH}$ & $56.38 \pm 3.86$ & $55.98 \pm 4.04$ & NS & $55.76 \pm 3.74$ & $54.79 \pm 3.98$ & NS & $56.71 \pm 3.86$ & $54.60 \pm 4.08$ & NS \\
\hline I-ML & $104.29 \pm 6.66$ & $104.12 \pm 5.37$ & NS & $99.85 \pm 5.89$ & $98.45 \pm 6.08$ & NS & $104.10 \pm 5.72$ & $102.34 \pm 5.36$ & $P=0.048^{*}$ \\
\hline CD & $59.04 \pm 8.50$ & $57.58 \pm 7.76$ & NS & $55.64 \pm 7.84$ & $55.03 \pm 7.45$ & NS & $58.68 \pm 7.94$ & $56.83 \pm 8.23$ & $P=0.038^{*}$ \\
\hline R1-R2 & $45.17 \pm 5.62$ & $44.53 \pm 6.12$ & NS & $42.83 \pm 5.73$ & $43.08 \pm 5.84$ & NS & $45.73 \pm 6.32$ & $45.12 \pm 4.89$ & NS \\
\hline R3-R4 & $28.32 \pm 4.32$ & $29.06 \pm 5.05$ & NS & $29.23 \pm 4.78$ & $28.65 \pm 5.32$ & NS & $30.54 \pm 4.75$ & $29.74 \pm 5.38$ & NS \\
\hline M1-M2 & $33.52 \pm 4.21$ & $34.85 \pm 5.43$ & NS & $34.45 \pm 6.23$ & $34.88 \pm 5.69$ & NS & $34.38 \pm 5.63$ & $33.60 \pm 4.79$ & NS \\
\hline GA & $122.81 \pm 5.79$ & $124.12 \pm 5.81$ & $=0.043^{*}$ & $122.68 \pm 7.86$ & $125.02 \pm 8.11$ & $=0.038^{*}$ & $123.21 \pm 8.43$ & $125.93 \pm 8.86$ & $P=0.045^{*}$ \\
\hline
\end{tabular}

NS, Not significant. *P<0.05 CH; Condylar Height, RH; Ramal Height, $\mathrm{CH}+\mathrm{RH}$; Condylar plus Ramal Height, I-ML; Corpus Length, CD; Corpus Base Length, R1-R2; Ramus Height, R3-R4; Ramus Width, M1-M2; Corpus Height, GA; Gonial Angle.

Table 4.

Statistical comparison of asymmetry measurements between groupsClass I, Class II and Class II subdivision samples

\begin{tabular}{|c|c|c|c|c|c|c|c|}
\hline \multirow{3}{*}{$\begin{array}{l}\text { Measurements } \\
\mathrm{CH}\end{array}$} & \multicolumn{2}{|c|}{ Class I } & \multicolumn{2}{|c|}{ Class II } & \multicolumn{2}{|c|}{ Class II Subdivision } & \multirow[b]{2}{*}{ Sign } \\
\hline & Mean $\pm S D$ & Min-Max & Mean \pm SD & Min-Max & Mean $\pm S D$ & Min-Max & \\
\hline & $2.85 \pm 1.28 \mathrm{~A}$ & $0.00-4.56$ & $3.34 \pm 1.45 \mathrm{~A}$ & $0.00-5.87$ & $6.85 \pm 5.56 \quad B$ & $0.00-22.43$ & * \\
\hline $\mathrm{RH}$ & $2.45 \pm 1.63$ & $0.12-6.24$ & $2.81 \pm 1.89$ & $0.08-7.59$ & $2.72 \pm 2.24$ & $0.18-8.04$ & NS \\
\hline $\mathrm{CH}+\mathrm{RH}$ & $2.14 \pm 2.02$ & $0.00-7.12$ & $2.65 \pm 2.42$ & $0.32-8.34$ & $3.32 \pm 2.08$ & $0.34-10.54$ & NS \\
\hline I-ML & $2.32 \pm 2.45 \mathrm{~A}$ & $0.22-9.12$ & $2.83 \pm 2.59 \mathrm{~A}$ & $0.23-8.57$ & $5.95 \pm 2.72 \quad B$ & $0.42-12.30$ & * \\
\hline CD & $2.89 \pm 2.12$ & $0.33-7.12$ & $2.98 \pm 2.67$ & $0.42-10.56$ & $3.63 \pm 2.68$ & $0.42-12.04$ & NS \\
\hline R1-R2 & $2.59 \pm 2.49$ & $0.00-6.55$ & $2.82 \pm 2.44$ & $0.23-7.12$ & $2.73 \pm 2.88$ & $0.44-8.82$ & NS \\
\hline R3-R4 & $2.63 \pm 2.39$ & $0.56-7.45$ & $2.89 \pm 2.90$ & $0.54-8.28$ & $2.68 \pm 2.96$ & $0.66-8.56$ & NS \\
\hline M1-M2 & $2.92 \pm 2.68$ & $0.44-8.54$ & $2.68 \pm 3.05$ & $0.39-9.12$ & $4.34 \pm 3.15$ & $0.55-9.84$ & NS \\
\hline GA & $2.86 \pm 2.04$ & $0.00-7.63$ & $3.23 \pm 2.56$ & $0.25-7.89$ & $2.78 \pm 2.49$ & $0.33-8.23$ & NS \\
\hline
\end{tabular}

NS, Not significant. *P<0.05 CH; Condylar Height, RH; Ramal Height, $\mathrm{CH}+\mathrm{RH}$; Condylar plus Ramal Height, l-ML; Corpus

Length, CD; Corpus Base Length, R1-R2; Ramus Height, R3-R4; Ramus Width, M1-M2; Corpus Height, GA; Gonial Angle. 
Descriptive statistics (mean, standard deviation, minimum, and maximum) and statistical comparisons of asymmetry indices of groups are shown in the Table 4. Kruskal-Wallis and post-hoc Mann-Whitney U tests revealed significant differences in condylar height and corpus length indices between groups $(P<0.05)$. Condylar height and corpus length indices were significantly higher in Group III (6.85 55.56 and $5.95 \pm 2.72$ in respectively) than the other groups (Group I= 2.85 \pm 1.28 and 2.32 \pm 2.45 , Group $I=$ $3.34 \pm 1.45$ and $2.83 \pm 2.59$ in respectively). There were no significant differences between the groups in any of the other analyzed measurement indices $(P>0.05)$.

\section{DISCUSSION}

Facial and craniofacial symmetry are referred as the 'state of equilibrium', whereby there is a concurrence in shape, size, and form between various structures on either side of the midline of the facial tissue (Duthie et al 2007). Therefore, both sides of the facial complex must be a mirror image of each other. However, there are dimensional differences in both sides and this situation may lead to harmony in face. Anthropologic and cephalometric studies have reported that there is no fully symmetrical facial complex and it should not be forgotten that the presence of small asymmetries of the face is natural (Letzer and Kronman 1967, Vig and Hewitt 1975, Veli et al 2011). The current study evaluated the prevalence of dimensional and angular asymmetries in Class II subdivision subjects compared with skeletal normal occlusion and Class II Div 1 malocclusion subjects.

If there are no skeletal mandibular positional asymmetries, Class II subdivision malocclusions are generally dentoalveolar and described as distal positioning of the mandibular first molar or mesial positioning of the maxillary first molars on Class II side (Alavi et al 1988, Rose et al 1994, Janson et al 2007). In present study, there were no skeletal asymmetries in Class II subdivision group. Therefore, in this group class II side could be caused distal positioning of the mandibular first molar or mesial positioning of the maxillary first molars.

The OPG is considered the current standard, for dental diagnosis, and especially so when dentists and orthodontists are devising a treatment plan. It has also been used for the assessment of side-to-side dimensional differences and to define the asymmetries (Habets et al 1987, Miller et al 1996, Miller et al 1997, Saglam 2003, Kiki et al 2007, Sezgin et al 2007, Kurt et al 2008). The use of OPG for specific measurements and the determination of differences is controversial owing to considerations relating to magnification and distortion. However, a number of studies have supported the use of the OPG technique, because obtaining an OPG is standard procedure and is favourable in terms of cost/benefit and only exposes subjects to relatively low doses of radiation (Habets et al 1987, Habets et al 1988, Bezuur et al 1989, Kambylafkas et al 2006). While, 3D computed tomography has some advantages compared with OPG, it is more expensive and labor intensive and entails higher radiation doses. On the other hand, assessment by 3D computed tomography is not ethical to confine to obtain $3 D$ computed tomography in normal occlusion subjects or Class II subdivision subjects. Therefore, the OPG used in this present study give sharply defined images of the mandibular structure.

The formula devised by Habets et al (1988) was used to determine the asymmetry index of measurements. The reliability of this formula has been shown in many studies (Habets et al 1988, Saglam 2003, Kiki et al 2007, Kilic et al 2008). The formula and method to assess the condylar and ramal asymmetry described by Habets et al (1988) has also been used in many studies. This formula utilizes absolute values to determine the asymmetry complex. In this present study, statistical tests showed that only condylar height and corpus length asymmetry indices were higher in the Class II subdivision group than in the other groups.

Many studies investigating the etiology of condylar asymmetry have shown that gender differences are not significant (Alavi et al 1988, Habets et al 1988, Rose et al 1994, Janson et al 2001, Saglam 2003, Azevedo et al 2006, Janson et al 2007, Kiki et al 2007, Kurt et al 2009). According to the Kiki et al (2007) there was no gender differences in condylar and ramal asymmetry in bilateral posterior crossbite subjects. Kurt et al (2008) investigated condylar and ramal asymmetry in Class II subdivision subjects, and found no significant gender differences when comparing sides. Sezgin et al (2007) found no gender differences in mandibular asymmetry when investigating different occlusion patterns. Therefore, the gender differences were not investigated in this present study.

Asymmetric malocclusions such as: unilateral crossbite, Class II subdivision, and cleft lip cause asymmetric development of the facial complex, but an important point is the degree of asymmetry (Kiki et al 2007, Kilic et al 2008, Kurt et al 2008). Kurt et al (2008) reported that condylar, ramal, and condylar-plus-ramal height values were significantly higher in the Class II subdivision group than the normal occlusion group and there were no significant differences in the asymmetry indices of measurements in the Class II subdivision group compared with mormal occlusion subjects. Janson et al (2001) and Azevedo et al (2006) found that vertical measurements values were higher in the Class II subdivision group than the normal 
occlusion subjects. In our study, asymmetry indexes of condylar, ramal, ramus, corpus, and gonial angle measurements were evaluated. The present study showed that condylar and corpus length asymmetry indexes were higher in the Class II subdivision group than the other groups. To our knowledge, other studies reported in the literature, which have investigated asymmetry indexes evaluated only condylar, ramal and condylar-plus-ramal asymmetry.

When harmony was compared between two sides in groups, Table 3 showed that there were differences between Class II subdivision group and other groups. In Class I and Class II groups there were only statistical differences in gonial angle (GA) measurements. However, in Class II subdivision group, there were statistical differences in condylar height $(\mathrm{CH})$, corpus length (I-ML), corpus base length (CD), and gonial angle (GA).

Habets et al (1988) described this method and formula first while evaluating the condylar and ramal asymmetriy in TMD subjects and in different malocclusions, and they have since been used often in asymmetry research. According to Habets et al (2006), asymmetry index values greater than $3 \%$ should be considered as vertical asymmetry, because a $3 \%$ index ratio may result from a $1 \mathrm{~cm}$ change in head position while obtaining the OPG. In the present study, condylar and gonial angle asymmetry indexes in the Class II group, condylar, condylar-plus-ramal, corpus length, corpus base length, and corpus width asymmetry indexes in the Class II subdivision group, and any in normal occlusion group were determined above $3 \%$. This result indicated that the Class II subdivision group exhibited more asymmetry of the mandible than the normal occlusion and Class II Div 1 malocclusion group.

Some authors have suggested that distal positioning of the mandibular molar is the main etiologic factor in the Class II subdivision with no evidence of skeletal asymmetry (Alavi et al 1988, Burstone 1998, Janson et al 2001, Azedevo et al 2006, Kurt et al 2008), whereas others, consistent with our study, have suggested skeletal aspects contribute to this malocclusion (Kula et al 1998, Janson et al 2007, Sanders 2010). Sanders et al (2010) investigated skeletal and dental asymmetry in Class II subdivision malocclusion using 3D modeling. They found that the most common factor was a deficient mandible, followed by mesial positioning of the maxillary first molars (20\%), then distal positioning of the mandibular first molar on the Class II side of the Class II subdivision malocclusions (19\%). On the other hand, Azevedo et al (2006) have reported that the main component of the Class II subdivision was dentoalveolar not skeletal or mandibular deficiency. The dentoalveolar components were primarily distal positioning of the first mandibular molar on the Class II side and secondarily mesial positioning of the maxillary molar on the same side.

Dimensional measurements could be determined by 2D imaging. Minor skeletal discrepancies are difficult and volumetric determinations are impossible to ascertain using 2D analysis methods and 2D imaging should be effected by distortion. Computed tomography is able to depict the three-dimensional morphology of the mandible and the asymmetry index could be determine by volumetric measurements; however, their use is limited by high irradiation, cost, and restricted accessibility. Another limitation of thi study should be Class II subdivision degrees. We determined at least half premolar mesio-distal length of Class II molar and canine relationship on Class II side in Class II subdivision group.

\section{CONCLUSIONS}

Within the limitations of this study, these findings demonstrated:

- Gonial angle measurement in all groups, condylar height, corpuslength and corpus base length measurements in Class II subdivision gorup showe significant differences between two sides.

- Condylar height and corpus length asymmetry index values were greater in the Class II subdivision group than in the normal occlusion and Class II Div 1 malocclusion group. This result indicates that the shape of mandible $s$ shape in subjects with Class II subdivision malocclusion was more unusual than normal occlusion and Class II Div 1 malocclusion. 


\section{Evaluation of mandibular asymmetry in class II subdivision malocclusion}

Background: The aim of this study was to determine the prevalence of mandibular skeletal asymmetries in Class II subdivision malocclusions as compared with the prevalence in Class I and Class II malocclusion.

Methods: The study consisted of 3 groups and each group included of 40 subjects: a Class I occlusion group (14 male and 26 female; mean age 14.68 \pm 1.86 ), a Class II occlusion group (12 male and 28 female; mean age $14.02 \pm 1.74)$, and a Class II subdivision occlusion group (19 male and 21 female; mean age 14.32 \pm 2.42 ). Eight linear measurements and one angular measurement were performed on the digital orthopantomograms (OPG) of each patient. The Wilcoxon test was used to compare the right and left side or Class I and Class II side measurements, the Kruskal-Wallis and post-hoc Mann-Whitney U-tests were used to assess intergroup comparisons of asymmetry at $P<0.05$ level.

Results: There was a significant difference only in gonial angle between right and left sides in Class I and Class II groups or Class I and Class II sides in Class II subdivision group $(\mathrm{P}<0.05)$. The condylar height and corpus length asymmetry indices were significantly greater in the Class II subdivision group than other groups $(P<0.05)$ and there was no significant differences detected between groups with regard to the other asymmetry indexes investigated ( $P>0.05)$.

Conclusions: Subjects in the Class II subdivision group have more asymmetrical mandibles when compared with subjects in the Class I and Class II groups.

\section{KEY WORDS}

Asymmetry, asymmetry index, class II subdivision, mandibular asymmetry

\section{REFERENCES}

Alavi DG, Begole EA, Schneider BJ, 1988. Facial and dental arch asymmetries in Class II subdivision malocclusion. Am J Orthod Dentofacial Orthop 93:3846.

Angle EH, 1899. Classification of malocclusion. Dental Cosmos 41:248-64.Peracini A, Andrade IM, Paranhos $\mathrm{H}$ de F, Silva $\mathrm{CH}$, de Souza RF, 2010. Behavior and hygiene habits of complete denture wearers. Braz Dent J, 21:247-52.
Azevedo AR, Janson G, Henriques JF et al, 2006. Evaluation of asymmetries between subjects with Class II subdivision and apparent facial asymmetry and those with normal occlusion. Am J Orthod Dentofacial Orthop 129:376-83.

Bezuur JN, Habets LL, Hansson TL, 1989. The recognition of craniomandibular disorders; condylar symmetry in relation to myogenous and arthrogenous origin of pain. $J$ Oral Rehabil 16:257-60.

Bock NC, Reiser B, Ruf S, 2013. Class II subdivision treatment with the Herbst appliance. Angle Orthod 83:327-33.

Burstone C, 1998. Diagnosis and treatment planning of patients with asymmetries. Semin Orthod 14:153-64.

Cheney E, 1952. The influence of dentofacial asymmetry upon treatment procedures. Am J Orthod 38:934-45.

Duthie J, Bharwani D, Tallents RH et al, 2007. A longitudinal study of normal asymmetric mandibular growth and its relationship to skeletal maturation. Am J Orthod Dentofacial Orthop 132:179-84.

Habets LL, Bezuur JN, Naeiji M et al, 1988. The Orthopantomogram, an aid in diagnosis of temporomandibular joint problems. II. The vertical symmetry. J Oral Rehabil 15:465-71.

Habets LL, Bezuur JN, van Ooij CP et al, 1987. The orthopantomogram, an aid in diagnosis of temporomandibular joint problems. I. The factor of vertical magnification. J Oral Rehabil 14:475-80.

Janson G, de Lima KJ, Woodside DG et al, 2007. Class II subdivision malocclusion types and evaluation of their asymmetries. Am J Orthod Dentofacial Orthop 131:57-66.

Janson G, Metaxas A, Woodside DG et al, 2001. Three-dimensional evaluation of skeletal and dental asymmetries in Class II subdivision malocclusions. Am J Orthod Dentofacial Orthop 119:406-18.

Joondeph DR, 2000. Mysteries of asymmetries. Am J Orthod Dentofacial Orthop 117:577-79.

Kambylafkas P, Murdock E, Gilda E et al, 2006. Validity of panoramic radiographs for measuring mandibular asymmetry . Angle Orthod 76:388-93.

Kiki A, Kilic N, Oktay H, 2007. Condylar asymmetry in bilateral posterior crossbite patients. Angle Orthod 77:77-81. 
Kilic N, Kiki A, Oktay H, 2008. Condylar asymmetry in unilateral posterior crossbite patients. Am $J$ Orthod Dentofacial Orthop 133:382-7.

Kula KA, Esmailnejad A, Hass A, 1998. Dental arch asymmetry in children with large overjets. Angle Orthod $68: 45-52$.

Kurt G, Uysal T, Sisman Y et al, 2008. Mandibular Asymmetry in Class II Subdivision Malocclusion. Angle Orthod 78:32-37.

Letzer GM, Kronman JH, 1967. A posteroanterior cephalometric evaluation of craniofacial asymmetry. Angle Orthod 37:205-11.

Miller VJ, Zeltser R, Zeltser $\mathrm{CH}$ et al, 1996. The condylar asymmetry-age relationship in determining myogenous or arthrogenous origin of pain in patients with temporomandibular disorders. J Oral Rehabil 23:392-94.

Miller VJ, 1997. Condylar asymmetry and handedness in patients with temporomandibular disorders. J Oral Rehabil 24: 549-51.

Ramirez-Yañez GO, Stewart A, Franken E, Campos K, 2011. Prevalence of mandibular asymmetries in growing patients. Eur J Orthod. 33:236-42.

Ricketts RM, 1961. Cephalometric analysis and synthesis. Angle Orthod 31:141-56.

Rose JM, Sadowsky C, Begole EA et al, 1994. Mandibular skeletal and dental asymmetry in Class II subdivision malocclusions. Am J Orthod Dentofacial Orthop 105:489-95.

Saglam AM, 2003. The condylar asymmetry measurements in different skeletal patterns. J Oral Rehabil 30:738-42.

Sanders DA, Rigali PH, Neace WP et al, 2010. Skeletal and dental asymmetries in Class II subdivision malocclusions using cone-beam computed tomography. Am J Orthod Dentofacial Orthop 138:542.e1-542.e20.

Sezgin OS, Celenk P, Arici S, 2007. Mandibular asymmetry in different occlusion patterns. Angle Orthod 77:803-7.

Veli I, Uysal T, Ucar FI et al, 2011. Cone-beam computed tomography assessment of mandibular asymmetry in unilateral cleft lip and palate patients. Korean $\mathrm{J}$ Orthod 41:431-39.

Vig PS, Hewitt AB, 1975. Asymmetry of the human facial skeleton. Angle Orthod 45:125-29.

Yazışma Adresi:

Dr. Mehmet AKIN

Selçuk Üniversitesi

Diş Hekimliği Fakültesi Ortodonti AD

Selçuklu - 42079 Kampus, Konya, Türkiye

Fax: + 903322410062

Phone : + 903322231167

E-mail: drmehmetakin07@gmail.com 